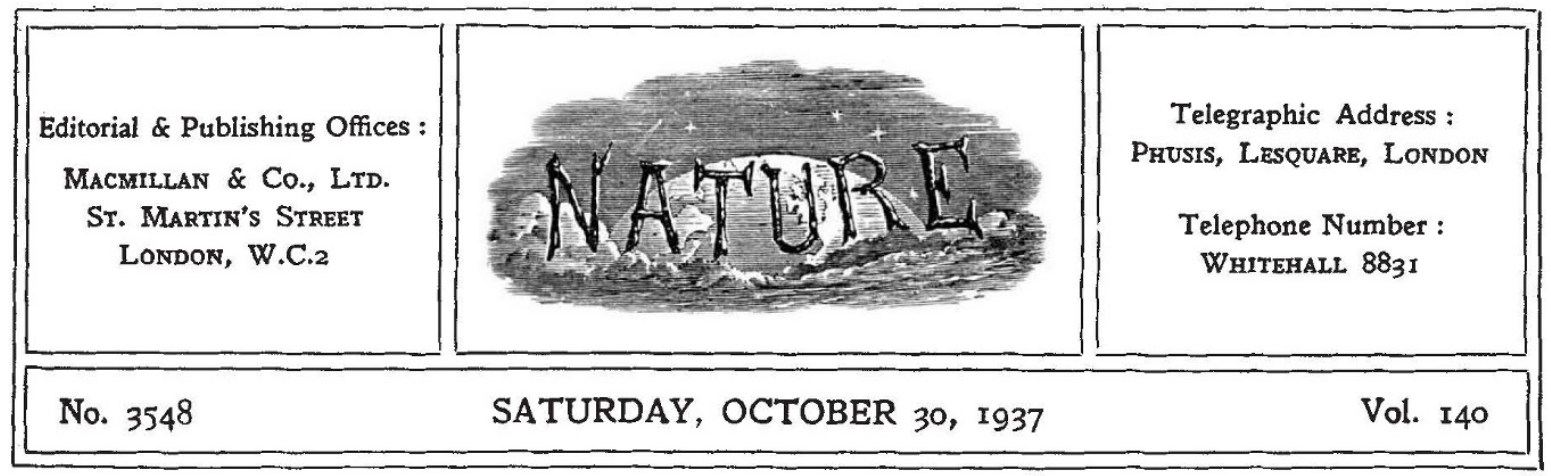

\title{
A Scientific Approach to the Colonial Problem
}

$\mathrm{T}$ HE Prime Minister has consented to receive a deputation on Monday next in support of a petition urging that the Government should take the initiative in promoting an inquiry into the fundamental causes of rivalry and unrest among the nations, by inviting all other fully self-governing States or Dominions to combine in setting up expert commissions to ascertain and report upon the basic facts in regard to such questions as access to raw materials and world markets, colonial development and the problem of surplus populations, etc. This proposal for fact-finding commissions is, of course, no novel idea; but the influential support which the petition has received indicates how rapidly the idea is gaining ground.

Already an inquiry into raw materials has been initiated by the League of Nations with the support of Great Britain, and the League Committee on Raw Materials has now completed its report. This inquiry is a direct outcome of an offer made by the British Government in 1935 and formally renewed in 1936. Even earlier, however, valuable work of this kind had been carried out in respect of problems concerned with the Pacific by the Institute of Pacific Relations, and the scientific study of similar problems affecting European relations was considered by a Conference for the Scientific Study of International Relations held at Copenhagen in June 1931.

While, however, the idea of impartial inquiry into the basic facts as a preliminary to concerted action designed to eliminate causes of friction is steadily gaining ground in public opinion, a good deal of valuable investigation is being quietly carried out by different organizations, the results of which have been published. Reference has been made above to the work of the Institute of Pacific Relations; and the situation in the Far East is the more regrettable because of the admirable work of the Kyoto and later Conferences.

In Great Britain the Royal Institute of International Affairs has already issued a number of valuable studies and reports such as "Raw Materials and Colonies" and "The Colonial Problem", which are only the latest and most detailed of them. In addition, other organizations are doing invaluable educational work, such as the New Commonwealth Institute, by means of its Information Bulletins, on questions of peaceful change and collective security, which not only prepare a wider circle of the public to accept the idea of the impartial investigation of such matters generally, but also assist materially in the formation of intelligent public opinion upon particular questions.

The League Committee for the Study of the Problem of Raw Materials has held three sessions, and the two sub-committees appointed to study the supply of raw materials and difficulties of purchase and payment have completed reports which are embodied in the final report. On the question of supply, the report indicates that while prohibition and restriction of raw materials might be justified as defensive measures, there are serious objections to their use for exercising pressure on other countries, for the preservation of uneconomic industries or for the maintenance of artificial price levels. It recommends accordingly that these obstacles should be removed as soon as possible and that nations should enter into agreements not to employ them. Similarly the Committee takes the view that 
countries controlling important quantities of raw materials should not place unreasonable obstacles in the way of those wishing to exploit these resources, and that their legislation should take account of the interdependence of nations as the basis of general welfare.

In common discussions this question of access to raw materials has been closely linked with the colonial question, and the League Committee's report indicates that some modification of the privileged situation which nationals of the mother country in fact enjoy in most colonial territories is desirable. Actual monopolies are rare, but the report clearly indicates the need for further investigation and study. Similarly the sub-committee dealing with obstacles to payment makes various suggestions for reducing existing restrictions on imports and exports by bilateral or multilateral action.

The League Committee's report includes, accordingly, a suggestion to re-examine the International Convention of 1927 for the Abolition of Import and Export Restrictions and Prohibitions, which should implement the resolution recently passed by the International Chamber of Commerce asserting that all countries should, so far as possible, have access to essential foodstuffs and raw materials. Much room is, however, still left for furthern ivestigation and discussion before an adequate and generally acceptable solution of the whole problem can be achieved. The appearance in the meantime of the latest report of the Institute of International Affairs* on the colonial problem is therefore particularly welcome. If its presentation is not all that could be desired-much of the third part, "Investment, Trade and Settlement", could with advantage have been dealt with earlier or incorporated in the appendixes, and the first part, "The International Aspect", should properly have followed the second, "The Colonial Aspect"it contains much information to clarify thought upon many of the proposals at present being debated, such as the extensions of the 'open-door' policy in colonial territories or the transfer of colonies into Mandated Territories or territories under international administration. The most valuable and significant part of the book is, in fact, the second part, in which the colonial aspect of the problem is considered, and especially the chapters in which the theory and practice of the present status of colonies are reviewed and the

* The Colonial Problem. A Report by a Study Group of Members of the Royal Institute of International Affairs. Pp. xiii +448 . (London, New York and Toronto: Oxford University Press, 1937). 218. net. importance of common principles of administration is stressed. The vast amount of exact information which it contains is, of course, the chief value of the book, but the task of sifting and selection cannot be pursued without judgment on the main issues. Particularly in this section of the report, the directions in which further inquiry is still called for are clearly indicated.

The dominant impression left on the mind by the survey presented in this part of the book is the immense field for co-operation and investigation which the colonial problem presents. It is seen not merely as a matter of immediate controversy, but rather as a constant problem the cure of which lies in the relations between economic and political aspects. The searching analysis which the study group gives of the way in which the democratic countries themselves are living up to the standards they profess shows no tendency to insist on the merits of British administration as opposed to those of other colonial Powers. In such questions as populations, the relative merits of plantations and native farming, labour policy, health services, education and nutrition, the report indicates the real problems to be faced and the need for research in British territories as elsewhere.

No scientific worker can read these chapters without realizing how large a contribution science itself has to make in providing a solution to these problems and assisting in the foundation of a wise policy. The possibilities for human happiness thus indicated make the present international clamour seem as stupid as it is threatening. Common principles of administration are essential because each of the colonial Powers is subjected to the same sort of criticism, whether from within or from without. Each suffers from the other's mistakes. The universal adoption of certain basic principles of justice towards non-colonial Powers and towards subject races is dictated by common prudence as well as by the more generous ideals of progressive civilization.

The colonial Powers must, in fact, prove to other Powers that their policy is not to exercise monopoly rights for themselves but rather to administer colonial resources in the general interest; and they must also prove to peoples in the Colonies that the protection and the administration they offer is a fair return for the taxation and the other obligations they impose, and is directed to ensure local prosperity. The report, indeed, suggests that in its international aspect the colonial problem is more than a grievance of particular "dissatisfied" 
nations against particular "satiated" nations : it is a grievance of the whole community of nations against the misuse, wherever it occurs, of colonial sovereignty. All departures from the principle of the 'open door' are an injustice to the international community.

The adoption of common principles of administration would facilitate transfer, but the division of Europe into democratic and authoritarian States complicates the issue greatly. Transference of mandates or colonial sovereignty to States repudiating the League Covenant, and with it the international machinery set up to promote international co-operation and to ensure common standards in the administration of subject peoples, would be an even greater injustice to the international community. There is, in fact, little in the report to hold out hope of meeting the needs of non-colonial Powers in terms of prestige and world power.

Though the difficulties in the way of transfer are clearly displayed, a number of concrete suggestions for meeting the needs of the noncolonial Powers by methods that do not involve transfer are indicated for securing equality of economic opportunity. Moreover, the facts in regard to access to raw materials are set forth in a way which scarcely upholds many of the contentions of the non-colonial Powers. If, for the moment, it is assumed that the correct view of the problem is how to make available the raw materials of industry, the report very effectively disposes of some of these illusions. Of the basic raw materials as defined by Dr. Goebbels himself, France, the United States and Russia produce between them 66 per cent of the world's iron ore ; the United States and the United Kingdom 54 per cent of the world's coal ; the United States, Russia and Venezuela 81 per cent of the world's oil; the United States, India and China 75 per cent of the world's cotton; Chile, the United States and Canada 49 per cent of the world's copper; and Malaya and the Dutch East Indies produce 83 per cent of the world's rubber.

Accordingly, the basic raw materials, with the exception of rubber, are produced mainly within the boundaries of sovereign States. Rubber alone is mainly a colonial product, but this raw material is open to purchase by all comers on equal terms, and there is no reason why foreign capital should not acquire rubber estates. Equal access is indeed given in enormous colonial areas, although considerable restrictions do exist upon free trade in colonial areas not covered by special treaties. An international agreement to guarantee equal commercial access over a much wider area, in accordance with a former principle of British colonial administration, should therefore do something to remove the feeling of non-colonial Powers that they may be cut off at any moment from access to all colonial supplies.

The problem of access to raw materials, therefore, is not the core of the colonial problem. The present study makes it clear that there is no simple solution and that the matter is one calling for the closest and most careful study. No hasty decisions are likely to be an easy way out of a dynamic but constant problem. The position of the colonial Powers is difficult. Mere transfer of colonial territories to the threatening States would not purchase safety and would be treachery to the colonial peoples and to the world community. The exposition of the facts given by the study group of the Royal Institute of International Affairs reinforces the need for some effective international organization and authority, such as the League of Nations, to which all colonial territories could ultimately be surrendered for administration under trust for the world community. Until that organization and authority are effectively established, the colonial Powers must perforce live dangerously, and their danger is best mitigated if their sovereignty is exercised in trust, first on behalf of the peoples inhabiting these areas and secondly for the wealth of all nations. In their own interests alone they must extirpate all taint of monopoly and exploitation.

Such a policy is not one of mere negation to the demands and aspirations of the dissatisfied or noncolonial Powers. It is essentially one of peaceful change, which offers the maximum inducement to participation in a system of international cooperation and collective security. Only as the facts are impartially assembled, and lucidly presented and clearly understood, can we hope to win acceptance of such ideas or policy, and the greatest merit of this volume is the weighty contribution it offers to the education of public opinion, in Great Britain no less than in other countries. Nor should it be forgotten there will still remain the task of organizing public opinion effectively everywhere to compel action in accordance with the facts, and to resist those nations who wantonly disregard them to the detriment of the community of nations. 